IRA-International Journal of Management \& Social Sciences

ISSN 2455-2267; Vol.06, Issue 03 (2017)

Pg. no. 354-364

Institute of Research Advances

https://research-advances.org/index.php/RAJMSS

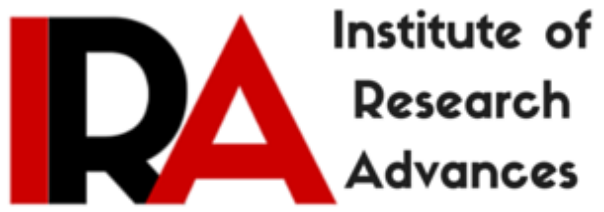

\title{
The Influence of Attitude, Knowledge and Quality on Purchase Intention towards Halal Food: A Case Study of Young Non-Muslim Consumers in Thailand
}

\author{
Kamonthip Maichum ${ }^{1}$, Surakiat Parichatnon ${ }^{2}$ and Ke-Chung Peng ${ }^{3}$ \\ 1,2 Department of Tropical Agriculture and International Cooperation, National Pingtung \\ University of Science and Technology, No.1, Shuefu Road, Neipu, Pingtung 91201, Taiwan. \\ ${ }^{3}$ Department of Agribusiness Management, National Pingtung University of Science and \\ Technology, No. 1, Shuefu Road, Neipu, Pingtung, 91201, Taiwan.
}

Type of Review: Peer Reviewed.

DOI: http://dx.doi.org/10.21013/jmss.v6.n3.p3

\section{How to cite this paper:}

Maichum, K., Parichatnon, S., \& Peng, K. (2017). The Influence of Attitude, Knowledge and Quality on Purchase Intention towards Halal Food: A Case Study of Young Non-Muslim Consumers in Thailand. IRA-International Journal of Management \& Social Sciences (ISSN 2455-2267), 6(3), 354-364. doi:http://dx.doi.org/10.21013/jmss.v6.n3.p3

(C) Institute of Research Advances

\section{(cc) EY-NO}

This work is licensed under a Creative Commons Attribution-Non Commercial 4.0 International License subject to proper citation to the publication source of the work.

Disclaimer: The scholarly papers as reviewed and published by the Institute of Research Advances (IRA) are the views and opinions of their respective authors and are not the views or opinions of the IRA. The IRA disclaims of any harm or loss caused due to the published content to any party. 


\begin{abstract}
This paper investigates the influence of attitude, halal knowledge, halal quality on purchase intention towards halal food of young non-Muslim consumers in Thailand. Consequently, total of 600 questionnaires were distributed and 482 usable responses were obtained yielding a response rate of $80.33 \%$. Our results indicated that attitude has a strongest direct influence on intention to purchase and also the results indicated that halal knowledge has a significant effect on attitude towards halal food and had no significant effect on halal purchase intention. Furthermore, halal quality has significant positive influences on the purchase intention among the studied group in Thailand. Therefore, this paper could provide insights important for manufacturers, marketers and policymakers to understand the perspectives of young non-Muslim consumers in Thailand.
\end{abstract}

Keywords: Attitude, Halal food, Halal knowledge, Halal quality, Purchase intention, Thailand, Young non-Muslim consumers

\title{
Introduction
}

In 2016, the global Muslim population was more than 2 billion, which spreading over 112 countries and is expected to increase by about 35\% in the next 20 years (Muslim, 2017). The majority of Muslims live in Asia, followed by Middle East and North Africa, sub-Saharan Africa, Europe, North America, Latin America and the Caribbean, respectively. In addition, Thailand had an estimated population at 70 million people and had an estimated Muslim population of about 7 million people, which accounts for $10 \%$ of the total population (NSO, 2016). Currently, the Muslim population is increasing rapidly; resulting in a demand for halal food has increased dramatically in recent years. Halal food refers to food that is permissible according to Islamic law. Therefore, halal food is a key to consumption for the Muslims.

Global halal market is estimated to be worth more than 2.3 trillion USD and the value of halal food is reaching 700 billion USD per year (Elasrag, 2016). Moreover, Muslims around the world who consume halal food and beverages is worth about 1,128 billion USD or about 17\% of global expenditure (Elasrag, 2016). Thailand is a leading exporter of halal products in Southeast Asia, as well as the world's fifth largest halal food exporter with 5.6\% share of the global halal food market valued at 5 billion USD a year annually (Abdul, 2014; Elasrag, 2016). Moreover, the Thai government has developed and improved several key strategies to strengthen the halal industry in the country and to reassure consumers of halal food in recognition of the quality and standards in the production of halal food in Thailand. Therefore, halal food has a very significant role both among Muslims and non-Muslims and has also very important to Thailand's economy.

Currently, the consumer awareness about the importance of healthy food, thereby influencing their food consumption behavior (Mathew, 2014), especially young consumers. Due to healthy foods can lead to protect the health and also help protect the environment as well (Chen, 2009). According to Lampila and Lähteenmäki (2007), the consumer acceptance is the important keys for their purchase intention and contributes to sustainable consumption. Khalek (2014) suggested that attitude towards halal food is essential in determining consumer behavior towards halal food. Shah Alam and Mohamed Sayuti (2011) reported that the attitude has a positive influence on purchase intention towards halal food among young consumers in Malaysia and moreover the consumers need to have enough understanding and knowledge to be able to choose halal food. In addition, Mohamed, Shamsudin, and Rezai (2013) observed that if consumers lack knowledge about halal food may affect their attitude and purchase intention. In Aziz and Chok (2013), the quality of halal food can be a source of product differentiation and is an important parameter for the food industry; therefore, understanding the relationship between the quality of halal food and consumer behavior is very important for producer and marketers. Many previous studies have 
been focused on the purchase intention towards halal food among young Muslim consumers (Khalek, 2014; Musa, 2014) but there are very few studies that focus on young non-Muslim consumers. Furthermore, Muhammad, Norhaziah, Nuradli, and Hartini (2007) concluded that the halal food is not only good for the Muslims but also good for everyone else. In Thailand, the majority of the population is Buddhist (94.6\%), thus there is a great need to study on non-Muslim consumers, which could indicate the important opportunity for this group to be a sustainable consumer of the halal market and could contribute more to the growth and development of halal food industry. Therefore, this study aimed to investigate the purchase intention towards halal food among young non-Muslim consumers and also to determine the relationship of attitude, halal knowledge and halal quality towards the purchase intention of young non-Muslim consumers in Thailand.

\section{Literature Review and Hypothesis Development}

The research framework used in this study is shown in Figure 1. In total, five hypotheses are drawn from four constructs, namely, attitude towards halal food, halal knowledge, halal quality and halal food purchase intention.

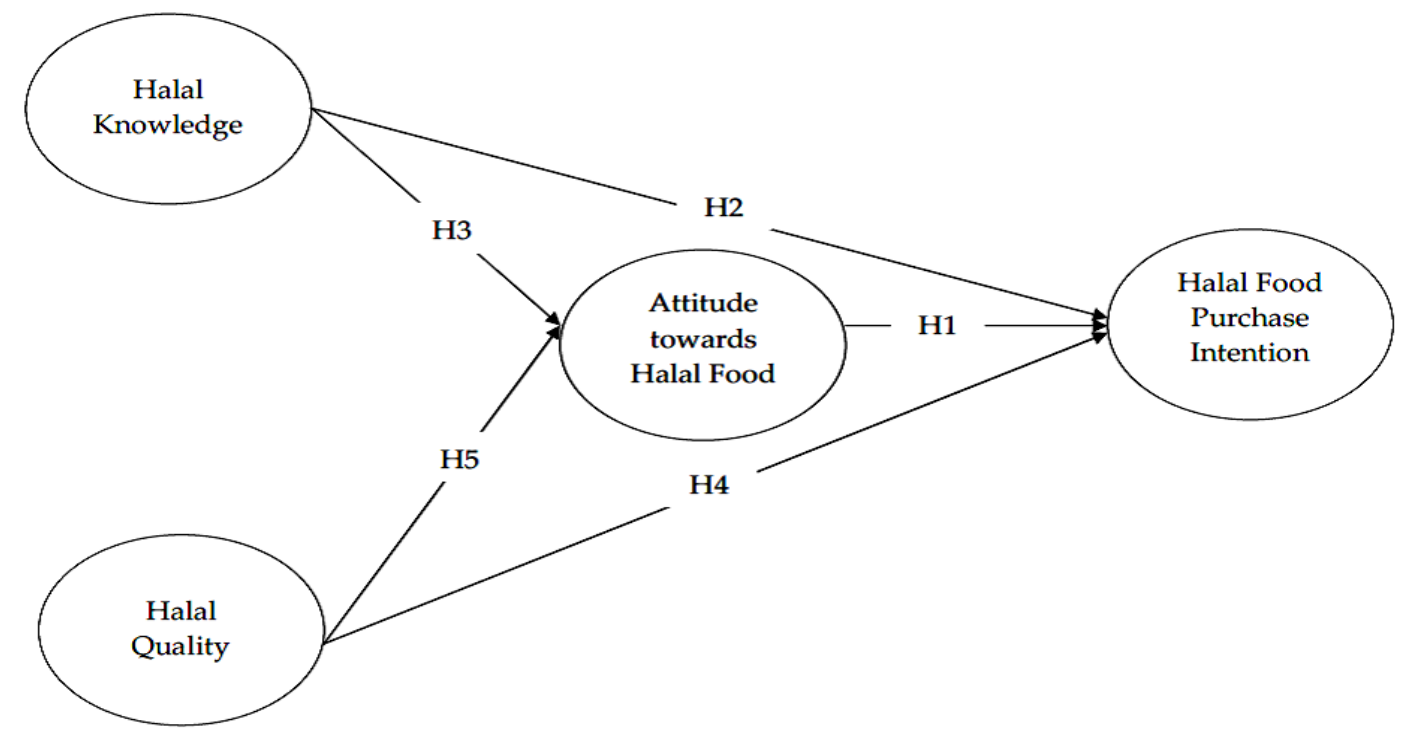

Figure 1. Conceptual model

\section{Halal Food Purchase Intention}

Purchase intention is the strongest indicators of the probability that a consumer will purchase a product or service. In addition, many researchers have proposed that the intention to purchase indicates an individual human belief to buy halal food (Nazahah \& Sutina, 2012; Yunus, Rashid, Ariffin, \& Rashid, 2014). Therefore, previous studies have shown that the purchase intention is strongly correlated with attitude, halal knowledge and halal quality (Jamal \& Sharifuddin, 2015; Khalek, 2014; Khalek \& Ismail, 2015; Mohamed Elias, 2016).

\section{Attitude towards Halal Food}

Attitude towards halal food refers to evaluate the favorable or unfavorable respondents to perform or not to perform behavior. Especially, the earlier studies have focused on the relationship between attitude towards halal food and purchase intention. For example, Shah Alam and Mohamed Sayuti (2011) reported that attitude towards halal food have a positive influence on purchase intention in Malaysia. Moreover, Khalek (2014) suggested that young consumer's 
purchasing intention is based on their attitude towards halal food. Thus, attitude towards halal food is regarded an important part of predicting and explaining the behavior of young consumers. Based on literature review, we propose the following hypotheses.

H1: Attitude towards halal food is positively associated with purchase intention for halal food of young non-Muslim consumers.

\section{Halal Knowledge}

Knowledge is one major factor that influences consumer's decision to purchase the products (Baharuddin, Kassim, Nordin, \& Buyong, 2015). Moreover, knowledge is important in creating the behavior of actual consumer purchase intention, especially towards halal food (Ahmad, Rahman, \& Ab Rahman, 2015; Sadeeqa, Sarrif, Masood, Saleem, \& Atif, 2013; Said, Hassan, Musa, \& Rahman, 2014). Hong and Sternthal (2010) pointed that the consumers who have less knowledge would much affect the evaluation of the product attributes. Mohamed Elias (2016) found that the positive relationship between halal knowledge and purchase intention towards halal food among university students in Malaysia. Mathew (2014) reported that the knowledge towards halal food influencing the acceptance of non-Muslim consumers. Therefore, halal knowledge is an important factor in encouraging purchase intention towards halal food and we propose that:

H2: Halal knowledge is positively associated with purchase intention for halal food of young nonMuslim consumers.

Simanjuntak and Dewantara (2014) suggested that the consumers' knowledge influences their attitude towards the product. Mostafa (2007) proposed that the knowledge has direct effects on their attitude and purchase intention. Furthermore, previous studies reported that the knowledge towards halal food has significant positive influence on consumers' attitude (Mohtar, Amirnordin, \& Haron, 2014; Simanjuntak \& Dewantara, 2014). Based on this discussion, we hypothesize that:

H3: Halal knowledge is positively associated with attitude towards halal food of young nonMuslim consumers.

\section{Halal Quality}

The quality of halal food is the most important factor for consumers in their decision to purchase the product and also important for manufacturers and marketers to improve product quality and increase customer value. Newberry, Klemz, and Boshoff (2003) reported that food quality was regarded as a parameter to predict the purchase intention. Namkung and Jang (2007) also showed that food quality has a positive influence on behavioral intention. According to Aziz and Chok (2013), halal food should be recognized that the high quality by the non-Muslim consumers, which has an impact on purchase intention. Therefore, we hypothesize that:

H4: Halal quality is positively associated with purchase intention for halal food of young nonMuslim consumers.

Halal quality has a direct impact on the attitude toward the product. Mohtar et al. (2014) concluded that halal quality positively influence the non-Muslim consumers' attitude towards halal food in Malaysia. As a result, we hypothesize that:

H5: Halal quality is positively associated with attitude towards halal food of young non-Muslim consumers. 


\section{Methodology}

The data used in this study were collected through a questionnaire by face to face interviews from young consumers in Thailand. Earlier studies have mentioned that young consumers are interested in a more sustainable behavior, as well as the purchase of halal food (Khalek, 2014; Musa, 2014). Therefore, the sample of this study was used to select respondents of or aged 18-30 that resided in Thailand. In addition, individual respondents who purchase halal foods in Thailand were considered to be the target population. A survey was conducted at halal shops, halal market, convenience store and department stores from September to November 2016. This study was conducted of two pilot tests. Firstly, we sampled 60 consumers who buy green products for testing the validity and reliability of the questionnaires. The items of questionnaire have been improved from the suggestions and comments of respondents to ease of understanding and more simplicity. After the first revision, the second pilot test of 60 consumers was performed to reevaluate the reliability. Finally, the questionnaire for data collection has been completed. A total of 600 questionnaires were distributed and 482 usable responses were obtained yielding a response rate of $80.33 \%$. From the Table 1 shown below, the majority of respondents were females $(55.60 \%)$, aged 18-23 years $(50.83 \%)$, single $(63.69 \%)$, Buddha $(60.17 \%)$, graduates with a bachelor's degree $(32.78 \%)$, with a family size of $2-3$ persons $(29.46 \%)$ and a monthly income ranged 5,001 $-10,000 \mathrm{THB}$ per person (1 USD $=34.6047 \mathrm{THB}$ as of 1 st September, 2016). The variables for each construct were modified from previous studies. This study has four constructs namely attitude towards halal food, halal knowledge, halal quality and halal food purchase intention. Therefore, the questionnaire items and sources of this study are provided in Table 2. Rankings of questionnaire items used the five-point Likert scale $(1=$ strongly disagree through $5=$ strongly agree). Moreover, data were analyzed using the statistical package for social sciences (SPSS 23.0) and analysis of moment structures (AMOS 19.0) software, to achieve the objectives and to test hypotheses of this study.

Table 1. Demographic characteristics of sample $(N=482)$

\begin{tabular}{llll}
\hline Items & Classification & Frequency & Percentage \\
\hline \multirow{2}{*}{ Gender } & Female & 268 & 55.60 \\
& Male & 214 & 44.40 \\
\hline \multirow{2}{*}{ Age } & $18-23$ years & 245 & 50.83 \\
& $24-30$ years & 237 & 49.17 \\
\hline \multirow{2}{*}{ Marital Status } & Single & 307 & 63.69 \\
& Married & 175 & 36.31 \\
\hline \multirow{4}{*}{ Religion } & Buddha & 290 & 60.17 \\
& Christian & 159 & 32.99 \\
& Hindu & 19 & 3.94 \\
& Others & 14 & 2.90 \\
\multirow{3}{*}{ Level of education } & Junior high school or less & 36 & 7.47 \\
& Senior high school & 73 & 15.14 \\
& Community college & 112 & 23.24 \\
& Bachelor & 158 & 32.78 \\
& Above bachelor & 103 & 21.37 \\
\hline
\end{tabular}


Table 1. Cont.

\begin{tabular}{llll}
\hline Items & Classification & Frequency & Percentage \\
\hline \multirow{3}{*}{ Family size } & 1 person & 102 & 21.16 \\
& $2-3$ persons & 142 & 29.46 \\
& $4-5$ persons & 132 & 27.39 \\
& More than 5 persons & 106 & 21.99 \\
\hline \multirow{4}{*}{ Monthly income } & Less than 5,000 THB & 91 & 18.88 \\
& $5,001-10,000 \mathrm{THB}$ & 175 & 36.31 \\
& $10,001-20,000 \mathrm{THB}$ & 139 & 28.84 \\
& $20,001-30,000 \mathrm{THB}$ & 63 & 13.07 \\
\hline
\end{tabular}

Table 2. The questionnaire items and sources

\begin{tabular}{|c|c|}
\hline Constructs / Questionnaire items & Sources \\
\hline $\begin{array}{l}\text { Attitude towards halal food (AT) } \\
\text { AT1: Halal food is safer compared to non halal food } \\
\text { AT2: Halal food is cleaner compared to non halal food } \\
\text { AT3: Halal food is healthier compared to than non halal food } \\
\text { AT4: I have a favorable attitude towards halal food }\end{array}$ & $\begin{array}{l}\text { Khalek and Ismail } \\
\text { (2015) and Khalek } \\
\text { (2014) }\end{array}$ \\
\hline $\begin{array}{l}\text { Halal knowledge (HK) } \\
\text { HK1: I understand about the halal-labels and certifications on halal } \\
\quad \text { food before purchase } \\
\text { HK2: I understand deeply about the inputs, processes and impacts of } \\
\quad \text { halal food before purchase } \\
\text { HK3: I would prefer to gain substantial information on halal food } \\
\quad \text { before purchase }\end{array}$ & $\begin{array}{l}\text { Ahmad et al. (2015) } \\
\text { and Said et al. (2014) }\end{array}$ \\
\hline $\begin{array}{l}\text { Halal quality (HQ) } \\
\text { HQ1: Halal food has an acceptable standard of quality } \\
\text { HQ2: Halal food has consistent quality } \\
\text { HQ3: Halal food is very good in taste and texture }\end{array}$ & $\begin{array}{l}\text { Jamal and Sharifuddin } \\
\text { (2015), Mohtar et al. } \\
\text { (2014) and Aziz and } \\
\text { Chok (2013) }\end{array}$ \\
\hline $\begin{array}{l}\text { Halal food purchase intention (PI) } \\
\text { PI1: I have a high intention to buy halal food } \\
\text { PI2: I buy halal food even if they are more expensive than non halal } \\
\text { food } \\
\text { PI3: I am likely to purchase any halal food }\end{array}$ & $\begin{array}{l}\text { Khalek and Ismail } \\
(2015), \text { Khalek (2014) } \\
\text { and Aziz and Chok } \\
(2013)\end{array}$ \\
\hline
\end{tabular}

\section{Results}

\section{Reliability and Validity of the Measurement Model}

The confirmatory factor analysis (CFA) was used to test and confirm the reliability and convergent validity of all constructs (e.g., attitude towards halal food, halal knowledge, halal quality and halal food purchase intention). According to Table 3, the reliability analysis showed that the Cronbach's $\alpha$ value ranged from 0.793 to 0.891 (e.g., halal knowledge is 0.793 , halal quality is 0.840 , attitude towards halal food is 0.860 and halal food purchase intention is 0.891 , respectively). Cronbach's $\alpha$ value of at least 0.700 is commonly seen as accepted (Nunnally \& Bernstein, 1994). Therefore, Cronbach's $\alpha$ value is recognized for reliability and these 
Cronbach's $\alpha$ values exceeded the standard value. The standardized factor loadings were between 0.683 and 0.910. Bagozzi and Yi (1988) proposed that the standardized factor loadings should be greater than 0.600 , thus, the standardized factor loadings of this study over the recommended value. Furthermore, the composite reliability (CR) estimates ranging from 0.811 to 0.906 , which are more than the recommended value of 0.700 and average variance extracted (AVE) range between 0.595 and 0.732 , which exceed the suggested value of 0.500 , as proposed by Alamsyah and Angliawati (2015) and Hair, Anderson, Tatham, and Black (1998). Table 4 shows that the results of the measurement model fit indices exceeded the acceptable levels (Steiger, 2007; Tabachnick, Fidell, \& Osterlind, 2001) as follows: $\chi^{2}=117.423(\mathrm{p}<0.001)$, df $=45, \chi^{2} / \mathrm{df}=$ 2.609 , GFI $=0.963$, AGFI $=0.921, \mathrm{RFI}=0.918, \mathrm{NFI}=0.936, \mathrm{CFI}=0.965, \mathrm{RMSEA}=0.064$, and $\mathrm{RMR}=0.036$. Thus, the results indicated that this measurement model had validity and reliability. Moreover, Table 5 shows that the descriptive statistics and correlations between constructs of this study.

Table 3. Validity of the measurement model

\begin{tabular}{|c|c|c|c|c|c|}
\hline Construct & $\begin{array}{l}\text { Question } \\
\text { item }\end{array}$ & $\begin{array}{l}\text { Cronbach's } \\
\text { alpha }\end{array}$ & $\begin{array}{l}\text { Standardized } \\
\text { factor loading }\end{array}$ & $\begin{array}{l}\text { Composite } \\
\text { reliability }\end{array}$ & $\begin{array}{l}\text { Average } \\
\text { variance } \\
\text { extracted }\end{array}$ \\
\hline \multicolumn{6}{|c|}{ Attitude towards halal food (AT) } \\
\hline & AT1 & \multirow[t]{4}{*}{0.860} & $0.794^{\mathrm{a}}$ & \multirow[t]{4}{*}{0.875} & \multirow[t]{4}{*}{0.683} \\
\hline & AT2 & & $0.812^{* * *}$ & & \\
\hline & AT3 & & $0.860^{* * *}$ & & \\
\hline & AT4 & & $0.841^{* * *}$ & & \\
\hline \multicolumn{6}{|c|}{ Halal knowledge (HK) } \\
\hline & HK1 & \multirow[t]{3}{*}{0.793} & $0.683^{\mathrm{a}}$ & \multirow[t]{3}{*}{0.811} & \multirow[t]{3}{*}{0.595} \\
\hline & HK2 & & $0.732^{* * * *}$ & & \\
\hline & HK3 & & $0.812^{* * *}$ & & \\
\hline \multicolumn{6}{|c|}{ Halal quality (HQ) } \\
\hline & HQ1 & \multirow[t]{3}{*}{0.840} & $0.758^{\mathrm{a}}$ & \multirow[t]{3}{*}{0.831} & \multirow[t]{3}{*}{0.623} \\
\hline & HQ2 & & $0.885^{* * *}$ & & \\
\hline & HQ3 & & $0.824^{* * * *}$ & & \\
\hline \multicolumn{6}{|c|}{ Halal food purchase intention (PI) } \\
\hline & PI1 & \multirow[t]{3}{*}{0.891} & $0.861^{\mathrm{a}}$ & \multirow[t]{3}{*}{0.906} & \multirow[t]{3}{*}{0.732} \\
\hline & PI2 & & $0.894^{* * *}$ & & \\
\hline & $\mathrm{PI} 3$ & & $0.910^{* * *}$ & & \\
\hline
\end{tabular}

Note: ${ }^{* * *} p<0.001,{ }^{a}$ Value was not calculated because loading was set to 1.000 to fix construct variance.

Table 4. Measurement model fit indices

\begin{tabular}{lll}
\hline & Criteria & Indicators \\
\hline Chi-square $\left(\chi^{2}\right)$ & $p>0.050$ & $117.423(p<0.001)$ \\
Chi-square/degree of freedom $\left(\chi^{2} / \mathrm{df}\right)$ & $<5.000$ & $2.609(117.423 / 45)$ \\
Goodness of Fit Index $(\mathrm{GFI})$ & $>0.900$ & 0.963 \\
Adjusted Goodness of Fit Index (AGFI) & $>0.900$ & 0.921 \\
Relative Fit Index (RFI) & $>0.900$ & 0.918 \\
Normed Fit Index (NFI) & $>0.900$ & 0.936 \\
Comparative Fit Index (CFI) & $>0.950$ & 0.965 \\
\hline
\end{tabular}




\begin{tabular}{lll}
\hline Root Mean Square Error of Approximation (RMSEA) & $<0.080$ & 0.064 \\
Root Mean Square Residual (RMR) & $<0.050$ & 0.036 \\
\hline
\end{tabular}

Table 5. Descriptive statistics and correlations between constructs

\begin{tabular}{lllll}
\hline & AT & HK & HQ & PI \\
\hline AT & 1.000 & & & \\
HK & $0.461^{* * *}$ & 1.000 & & \\
HQ & $0.439^{* * *}$ & $0.395^{* * *}$ & 1.000 & \\
PI & $0.427^{* * *}$ & $0.337^{* * *}$ & $0.476^{* * *}$ & 1.000 \\
\hline Mean & 4.214 & 3.559 & 4.016 & 4.339 \\
Standard Deviation & 0.743 & 0.965 & 0.841 & 0.732 \\
\hline
\end{tabular}

Note: ${ }^{* * *} p<0.001$.

\section{Hypotheses Testing}

Figure 2 provides details of the results of research model. According to the results in Table 6 , the results of the model fit were higher than the recommended values and showed that the model fit the data very well $\left(\chi^{2}=212.396(p<0.001), \mathrm{df}=58, \chi^{2} / \mathrm{df}=3.662, \mathrm{GFI}=0.969\right.$, AGFI $=0.924$, $\mathrm{RFI}=0.921, \mathrm{NFI}=0.945, \mathrm{CFI}=0.972, \mathrm{RMSEA}=0.055$ and $\mathrm{RMR}=0.027)$. Furthermore, Table 7 reports the hypotheses and the estimates of the research model. Totally, four out of five hypotheses are supported. First, attitude towards halal food had significant positive influences on halal food purchase intention $(\mathrm{H} 1: \beta 1=0.632, \mathrm{t}=20.451, p<0.001)$, thus supporting $\mathrm{H} 1$. Second, halal knowledge showed no significant influences on halal food purchase intention $(\mathrm{H} 2$ : $\beta 2=0.102, \mathrm{t}=0.984)$ and has direct positive effects on attitude towards halal food $(\mathrm{H} 3: \beta 3=$ $0.315, \mathrm{t}=8.693, p<0.01$ ). Thus, $\mathrm{H} 2$ was rejected, while $\mathrm{H} 3$ was supported. Finally, halal quality had significant positive effects on halal food purchase intention ( $\mathrm{H} 4: \beta 4=0.461, \mathrm{t}=15.438, p<$ $0.001)$ as well as attitude towards halal food (H5: $\beta 5=0.357, \mathrm{t}=10.480, p<0.01)$. In this case H4 and H5 were supported.

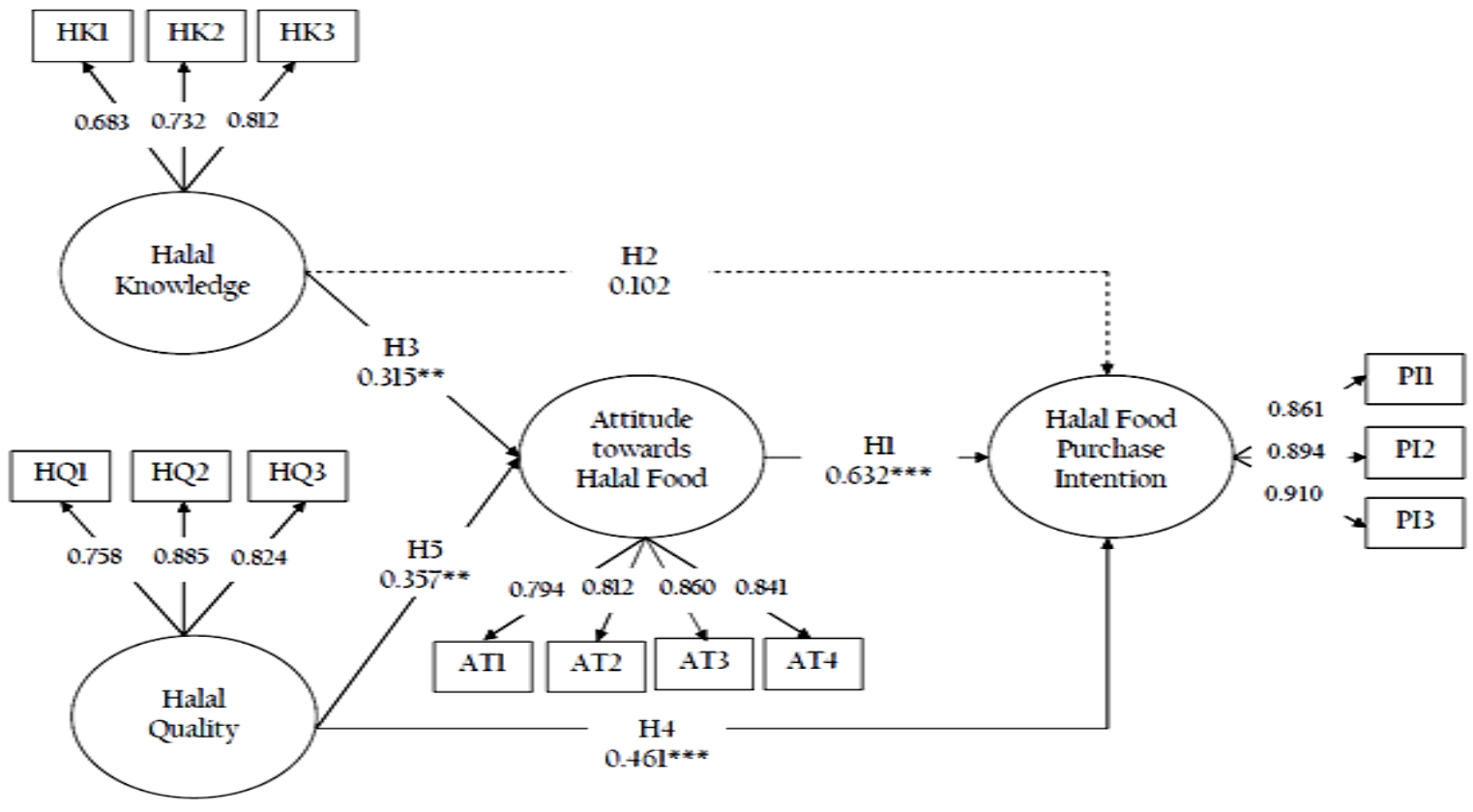


Table 6. Goodness of fit indices

\begin{tabular}{lll}
\hline & Criteria & Indicators \\
\hline Chi-square $\left(\chi^{2}\right)$ & $p>0.050$ & $212.396(p<0.001)$ \\
Chi-square/degree of freedom $\left(\chi^{2} / \mathrm{df}\right)$ & $<5.000$ & $3.662(212.396 / 58)$ \\
Goodness of Fit Index (GFI) & $>0.900$ & 0.969 \\
Adjusted Goodness of Fit Index (AGFI) & $>0.900$ & 0.924 \\
Relative Fit Index (RFI) & $>0.900$ & 0.921 \\
Normed Fit Index (NFI) & $>0.900$ & 0.945 \\
Comparative Fit Index (CFI) & $>0.950$ & 0.972 \\
Root Mean Square Error of Approximation (RMSEA) & $<0.080$ & 0.055 \\
Root Mean Square Residual (RMR) & $<0.050$ & 0.027 \\
\hline
\end{tabular}

Table 7. Hypotheses results for the structural model

\begin{tabular}{|c|c|c|c|c|}
\hline Hypothesis & Path correlation & $\begin{array}{l}\text { Standardized } \\
\text { estimates }\end{array}$ & t-Value & $\begin{array}{l}\text { Test } \\
\text { result }\end{array}$ \\
\hline H1 & $\begin{array}{l}\text { Attitude towards halal food } \rightarrow \\
\text { Halal food purchase intention }\end{array}$ & $0.632 * * *$ & 20.451 & Support \\
\hline $\mathrm{H} 2$ & $\begin{array}{l}\text { Halal knowledge } \rightarrow \\
\text { Halal food purchase intention }\end{array}$ & 0.102 & 0.984 & Reject \\
\hline $\mathrm{H} 3$ & $\begin{array}{l}\text { Halal knowledge } \rightarrow \\
\text { Attitude towards halal food }\end{array}$ & $0.315^{* *}$ & 8.693 & Support \\
\hline $\mathrm{H} 4$ & $\begin{array}{l}\text { Halal quality } \rightarrow \\
\text { Halal food purchase intention }\end{array}$ & $0.461 * * *$ & 15.438 & Support \\
\hline H5 & $\begin{array}{l}\text { Halal quality } \rightarrow \\
\text { Attitude towards halal food }\end{array}$ & $0.357 * *$ & 10.480 & Support \\
\hline
\end{tabular}

\section{Discussion and conclusions}

This study investigated the determinants that influence young non-Muslim consumers' intention to purchase toward halal food in Thailand. The overall results confirmed that the attitude towards halal food has a strongest direct influence on halal food purchase intention among the young nonMuslim consumers in Thailand. The study therefore shows that if they have a positive attitude and will influence their purchase intention towards halal food, which make them buy more and more often. Khalek (2014) reported a positive impact of attitude on halal food purchase intention among students in Malaysia. Halal knowledge reported a significant positive effect on attitude towards halal food and on the other hand, halal knowledge failed to provide any positive thrust concerning a reason of purchase intention, which supported the findings of Mohamed Elias (2016). Furthermore, the empirical finding reported that halal quality had significant positive influence on attitude and purchase intention towards halal food among consumers. This study could help guide manufacturers, marketers and policy makers to understand the influence on intention to purchase towards halal food of young non-Muslim consumers in Thailand. Therefore, future research would recommend to explore the other factors, may focus on different demographics and in addition to increasing the number of samples, which may result in a much stronger research. 
IRA-International Journal of Management \& Social Sciences

\section{References}

1. Abdul, M. (2014). Perceptions on Halal food certification in Hat Yai, Thailand. International Journal of Economics and Management, 8(1), 178-194.

2. Ahmad, A. N., Rahman, A. A., \& Ab Rahman, S. (2015). Assessing knowledge and religiosity on consumer behavior towards halal food and cosmetic products. International Journal of Social Science and Humanity, 5(1), 10.

3. Alamsyah, D. P., \& Angliawati, R. Y. (2015). Buying behavior of organic vegetables product: The effects of perceptions of quality and risk. International Journal of Scientific and Technology Research, 4(12), 28-35.

4. Aziz, Y. A., \& Chok, N. V. (2013). The role of Halal awareness, Halal certification, and marketing components in determining Halal purchase intention among non-Muslims in Malaysia: a structural equation modeling approach. Journal of International Food \& Agribusiness Marketing, 25(1), 1-23.

5. Bagozzi, R. P., \& Yi, Y. (1988). On the evaluation of structural equation models. Journal of the academy of marketing science, 16(1), 74-94.

6. Baharuddin, K., Kassim, N. A., Nordin, S. K., \& Buyong, S. Z. (2015). Understanding the halal concept and the importance of information on halal food business needed by potential Malaysian entrepreneurs. International Journal of Academic Research in Business and Social Sciences, 5(2), 170.

7. Chen, M. F. (2009). Attitude toward organic foods among Taiwanese as related to health consciousness, environmental attitudes, and the mediating effects of a healthy lifestyle. British Food Journal, 111(2), 165-178.

8. Elasrag, H. (2016). Halal Industry: Key Challenges and Opportunities: Hussein Elasrag.

9. Hair, J., Anderson, R., Tatham, R., \& Black, W. (1998). Conjoint analysis. Multivariate data analysis, 387-441.

10. Hong, J., \& Sternthal, B. (2010). The effects of consumer prior knowledge and processing strategies on judgments. Journal of marketing research, 47(2), 301-311.

11. Jamal, A., \& Sharifuddin, J. (2015). Perceived value and perceived usefulness of halal labeling: The role of religion and culture. Journal of Business Research, 68(5), 933-941.

12. Khalek, A. A. (2014). Young consumers' attitude towards halal food outlets and JAKIM's halal certification in Malaysia. Procedia-Social and Behavioral Sciences, 121, 26-34.

13. Khalek, A. A., \& Ismail, S. H. S. (2015). Why are we eating halal-using the theory of planned behavior in predicting halal food consumption among generation $\mathrm{Y}$ in Malaysia. International Journal of Social Science and Humanity, 5(7), 608.

14. Lampila, P., \& Lähteenmäki, L. (2007). Consumers' attitudes towards high pressure freezing of food. British Food Journal, 109(10), 838-851.

15. Mathew, V. N. (2014). Acceptance on Halal food among non-Muslim consumers. Procedia-Social and Behavioral Sciences, 121, 262-271.

16. Mohamed Elias, E., Othman, S. N., \& Mohd Saifudin, A. (2016). Halal awareness and knowledge among Muslim's student entrepreneurship program: A preliminary study. Paper presented at the In: 2nd International Conference on Global Social Entrepreneurship (2nd ICoGBSE2016), 13-14 March 2016, Koh Samui, Thailand.

17. Mohamed, Z., Shamsudin, M. N., \& Rezai, G. (2013). The effect of possessing information about halal logo on consumer confidence in Malaysia. Journal of International Food \& Agribusiness Marketing, 25, 73-86.

18. Mohtar, N. M., Amirnordin, N. A., \& Haron, H. (2014). Ayamas Food Corporation Sdn. Bhd: A Study on the Factors of Consumer Behaviour towards Halal Product Selection. Procedia-Social and Behavioral Sciences, 121, 166-185. 
19. Mostafa, M. M. (2007). A hierarchical analysis of the green consciousness of the Egyptian consumer. Psychology \& Marketing, 24(5), 445-473.

20. Muhammad, N., Norhaziah, N., Nuradli, R., \& Hartini, M. (2007). Halal Branding: An Exploratory Research among consumers in Malaysia.

21. Musa, R. (2014). Factors influencing attitude towards halal cosmetic among young adult Urban Muslim women: A focus group analysis. Procedia-Social and Behavioral Sciences, 130, 129-134.

22. Muslim. (2017). Muslim Population. Available at http://muslimpopulation.com/world/. Retrieved on January 22, 2017. .

23. Namkung, Y., \& Jang, S. (2007). Does food quality really matter in restaurants? Its impact on customer satisfaction and behavioral intentions. Journal of Hospitality \& Tourism Research, 31(3), 387-409.

24. Nazahah, A., \& Sutina, J. (2012). The halal product acceptance model for the religious society. Business \& Management Quarterly Review, 3 (1), 17-25.

25. Newberry, C. R., Klemz, B. R., \& Boshoff, C. (2003). Managerial implications of predicting purchase behavior from purchase intentions: a retail patronage case study. Journal of Services Marketing, 17(6), 609-620.

26. NSO. (2016). The 2015 household socio-economic survey whole Kingdom. National Statistics Office, Bangkok, Thailand.

27. Nunnally, J. C., \& Bernstein, I. (1994). Elements of statistical description and estimation. Psychometric Theory 3 Edition (Edited by: Nunnally JC, Bernstein IH).

28. Sadeeqa, S., Sarrif, A., Masood, I., Saleem, F., \& Atif, M. (2013). Knowledge, attitude and perception (KAP) regarding halal pharmaceuticals among general public in Penang state of Malaysia. International Journal of Public Health Science, 2(4), 143-150.

29. Said, M., Hassan, F., Musa, R., \& Rahman, N. (2014). Assessing consumers' perception, knowledge and religiosity on Malaysia's halal food products. Procedia-Social and Behavioral Sciences, 130, 120-128.

30. Shah Alam, S., \& Mohamed Sayuti, N. (2011). Applying the theory of planned behavior (TPB) in halal food purchasing. International Journal of Commerce and Management, 21(1), 8-20.

31. Simanjuntak, M., \& Dewantara, M. M. (2014). The effects of knowledge, religiosity value, and attitude on halal label reading behavior of undergraduate students. ASEAN Marketing Journal, 6(2), 65-76.

32. Steiger, J. H. (2007). Understanding the limitations of global fit assessment in structural equation modeling. Personality and Individual differences, 42(5), 893-898.

33. Tabachnick, B. G., Fidell, L. S., \& Osterlind, S. J. (2001). Using multivariate statistics.

34. Yunus, N. S. N. M., Rashid, W. E. W., Ariffin, N. M., \& Rashid, N. M. (2014). Muslim's Purchase Intention towards Non-Muslim's Halal Packaged Food Manufacturer. ProcediaSocial and Behavioral Sciences, 130, 145-154. 